\title{
EGFR T790M Detection in Circulating Tumor DNA from Non-small Cell Lung Cancer Patients Using the PNA-LNA Clamp Method
}

\author{
HIRONORI YOSHIDA, YOUNG HAK KIM, HIROAKI OZASA, HIROKI NAGAI, YUICHI SAKAMORI, \\ TAKAHIRO TSUJI, TAKASHI NOMIZO, TOMOKO FUNAZO, YUTO YASUDA and TOYOHIRO HIRAI \\ Department of Respiratory Medicine, Graduate School of Medicine, Kyoto University, Kyoto, Japan
}

\begin{abstract}
Aim: To evaluate the utility of plasma circulating tumor DNA (ctDNA) using the peptide nucleic acid-locked nucleic acid (PNA-LNA) clamp method to detect epidermal growth factor receptor (EGFR) mutations in non-small cell lung cancer (NSCLC) patients who had progressed under treatment with EGFR-tyrosine kinase inhibitors (TKIs). Patients and Methods: Blood samples were collected from patients with EGFR mutation-positive NSCLC who had progressed on EGFR-TKIs between March 2016 and August 2016 at the Kyoto University Hospital. Extracted ctDNA was analyzed using the PNALNA clamp method. In eligible patients, tissue re-biopsy was also performed and EGFR mutation status was compared between tissue and plasma samples. Results: Thirty-one patients were enrolled in this study. Known activating EGFR mutations and the T790M mutation were detected in $18(58 \%)$ and 5 patients (16\%), respectively. Twenty-five patients underwent tissue re-biopsy. Adequate samples for mutation analysis were obtained from 21 patients and 10 patients were found to be tissue T790Mpositive. Among these 10 patients, 4 patients were positive for T790M in plasma ctDNA (sensitivity 40\% and specificity 100\%). All patients with T790M-positive plasma ctDNA responded to osimertinib. Conclusion: Sensitivity of the PNA-LNA clamp method in detecting the plasma EGFR T790M mutation was moderate with elevated, however, specificity. Plasma EGFR T790M testing may be adequate for the initial step; however, tissue re-biopsy
\end{abstract}

Correspondence to: Young Hak Kim, MD, Department of Respiratory Medicine, Graduate School of Medicine, Kyoto University, 54 Shogoin-Kawaharacho, Sakyo-ku, Kyoto 606-8507, Japan. Tel: +81 757513830, Fax: +81 757514643, e-mail: ekim@kuhp.kyoto-u.ac.jp

Key Words: EGFR T790M, EGFR-TKI, circulating tumor DNA, PNA-LNA clamp method, non-small cell lung cancer. should be considered for plasma T790M-negative patients because of its high false-negative rate.

Despite initial responses to epidermal growth factor receptor-tyrosine kinase inhibitors (EGFR-TKIs), most patients eventually develop drug resistance and relapse around 12 months after treatment initiation (1-3). The EGFR T790M mutation has been reported to be a major resistance mechanism accounting for approximately 50 $60 \%$ of acquired resistance to EGFR-TKIs (4). A previous study demonstrated that osimertinib, a third-generation EGFR-TKI, has clinical activity for patients with $E G F R$ T790M-positive non-small cell lung cancer (NSCLC) (5, 6). Consequently, T790M mutation has become a new biomarker for guidance of treatment after the failure of first- or second-generation EGFR-TKIs. Although tissue rebiopsy is recommended to confirm this mutation, obtaining sufficient tissue for mutation analysis is not always easy. Thus, non-invasive genotyping of plasma circulating tumor DNA (ctDNA) has been developing as an alternative method (7-9).

To date, several studies have reported that the EGFR mutation status detected in plasma ctDNA was highly concordant with that detected in tumor tissue (10-12); however, data are still insufficient and tissue-based testing is considered to be a gold standard. This study aimed to evaluate the utility of plasma ctDNA for EGFR mutation detection using the peptide nucleic acid-locked nucleic acid (PNA-LNA) clamp method in NSCLC patients who had progressed on EGFR-TKIs.

\section{Patients and Methods}

Patients were recruited between March 2016 and August 2016 at Kyoto University Hospital, Kyoto, Japan. All patients had advanced EGFR mutation-positive NSCLC and were under previous EGFRTKIs. Patients were excluded if they had de novo T790M mutation before EGFR-TKI treatment. Whole blood samples $(14 \mathrm{ml})$ were collected in ethylenediaminetetraacetic acid (EDTA) tubes. Samples 
were mixed thoroughly and plasma was isolated by centrifugation at $1,700 \times g$ for $10 \mathrm{~min}$ at room temperature was stored at $-80^{\circ} \mathrm{C}$ until DNA extraction. EGFR mutations, G719X, exon 19 deletion, T790M, L858R and L861Q were analyzed in the central laboratory, LSI Medience Corporation (Kyoto, Japan) using the PNA-LNA clamp method. The laboratory procedures for mutation detection were the same as previously described $(13,14)$. In addition, tissue re-biopsy was also performed on eligible patients and EGFR mutation in tissue samples was analyzed by the PNA-LNA clamp method as well. Concordance of EGFR mutation status between matched samples from tissue re-biopsy and plasma ctDNA was assessed by sensitivity and specificity. Objective tumor response was evaluated in accordance with the Response Evaluation Criteria in Solid Tumors (RECIST) 1.1. Progression-free survival (PFS) was defined as the period from the date of initiation of osimertinib treatment to the date of disease progression or death due to any cause. Written informed consent was obtained from all participants. This study was approved by the ethics committee of Kyoto University (Kyoto, Japan).

\section{Results}

Patients' characteristics. Blood samples were collected from 31 patients between March 2016 and August 2016. Clinical characteristics of the 31 patients are listed in Table I. Median age was 66 (range=39-82) years. Twenty patients had never smoked. Regarding the EGFR mutation subtype, exon 19 deletion was detected in 15 patients, L858R mutation in 15 patients, while an uncommon mutation was found in one patient.

Plasma ctDNA analysis. Thirty-one plasma samples were analyzed for EGFR mutation status. Of the 31 samples, the known activating EGFR mutations and T790M mutation were detected in $18(58 \%)$ and 5 samples (16\%), respectively, whereas 13 of the 31 plasma samples were negative for both the known activating EGFR mutations and T790M mutation. Sensitivity of plasma genotyping for the known EGFR mutations was $60 \%$ for both exon 19 deletion and L858R mutation.

EGFR mutation status between tissue and plasma samples. Tissue re-biopsy samples were obtained from 25 patients, including primary lesions from 16 patients, pleural effusion from 5 patients, lung metastases from two patients, bone metastases from one patient and liver metastases from one patient. Among them, 21 samples were adequate for mutation analysis; three tissue samples did not include malignant cells and one sample was transforming to small cell lung carcinoma.

The results of known activating EGFR mutation and T790M mutation analysis of tissue samples and plasma samples from 21 patients are listed in Table II. Ten were positive for exon 19 deletion and 11 were positive for L858R mutation. Thus, the sensitivity of plasma genotyping was $60 \%$ for exon 19 deletion and $64 \%$ for L858R mutation. T790M was detected in 10 patients $(48 \%)$. Of those 10 patients, four patients were T790M-positive in plasma samples $($ sensitivity $=40 \%)$. In contrast, T790M was not
Table I. Patients' characteristics.

\begin{tabular}{lc}
\hline Characteristic & Patients $(\mathrm{n}=31)$ \\
\hline Median age (range) & $66(39-82)$ \\
Gender & \\
Male & $17(55 \%)$ \\
Female & $14(45 \%)$ \\
Smoking status & \\
Never & $20(65 \%)$ \\
Current/former & $11(35 \%)$ \\
ECOG PS & $25(81 \%)$ \\
$0-1$ & $6(19 \%)$ \\
2 & $15(48 \%)$ \\
Types of EGFR mutation & $15(48 \%)$ \\
Exon 19 deletion & $1(3 \%)$ \\
L858R & \\
uncommon & $18(58 \%)$ \\
Previous EGFR-TKI treatment & $18(58 \%)$ \\
Gefitinib & $13(42 \%)$ \\
Erlotinib & \\
Afatinib & \\
\hline
\end{tabular}

ECOG, Eastern Cooperative Oncology Group; PS, performance status; EGFR, epidermal growth factor receptor; TKI, tyrosine kinase inhibitor.

Table II. Sensitivity and specificity of plasma ctDNA for EGFR mutation compared with tissue re-biopsy sample as a reference.

\begin{tabular}{lcc}
\hline Plasma $(\mathrm{n}=21)$ & \multicolumn{2}{c}{ Tissue $(\mathrm{n}=21)$} \\
\cline { 2 - 3 } & Exon 19 del $+(\mathrm{n}=10)$ & Exon 19 del $-(\mathrm{n}=11)$ \\
\hline Exon 19 del + $(\mathrm{n}=6)$ & $6(60 \%$ sensitivity $)$ & 0 \\
Exon 19 del $-(\mathrm{n}=15)$ & 4 & $11(100 \%$ specificity $)$ \\
L858R $+(\mathrm{n}=7)$ & L858R $+(\mathrm{n}=11)$ & L858R $-(\mathrm{n}=10)$ \\
L858R $-(\mathrm{n}=14)$ & $7(64 \%$ sensitivity $)$ & 0 \\
& 4 & $10(100 \%$ specificity $)$ \\
T790M $+(\mathrm{n}=4)$ & T790M $+(\mathrm{n}=10)$ & T790M $-(\mathrm{n}=11)$ \\
T790M $-(\mathrm{n}=17)$ & $4(40 \%$ sensitivity $)$ & 0 \\
\hline
\end{tabular}

ctDNA, Circulating tumor DNA; EGFR, epidermal growth factor receptor.

detected in 11 patients $(52 \%)$ in tissue samples, while all of them were T790M-negative (specificity $=100 \%$ ).

Comparison of plasma T790M-positive and-negative patient characteristics among the tissue T790M-positive patients. Of the 10 tissue T790M-positive patients, four patients were plasma T790M-positive and six patients plasma T790M-negative (Table III). The number of prior EGFR-TKI regimens was higher for plasma T790M-positive patients. All plasma T790M-positive patients were M1b and the serum carcinoembryonic antigen (CEA) level was higher for plasma T790M-positive patients. 
Table III. Comparison of plasma T790M-positive and -negative patients' characteristics among tissue T790M-positive patients $(N=10)$.

\begin{tabular}{|c|c|c|}
\hline \multirow[t]{2}{*}{ Characteristics } & \multicolumn{2}{|c|}{$\mathrm{T} 790 \mathrm{M}$ in plasma } \\
\hline & Positive $(\mathrm{N}=4)$ & Negative $(\mathrm{N}=6)$ \\
\hline Median age (range), years & $58.5(49-69)$ & $72(54-73)$ \\
\hline \multicolumn{3}{|l|}{ Gender } \\
\hline Male & 1 & 4 \\
\hline Female & 3 & 2 \\
\hline \multicolumn{3}{|l|}{ Smoking status } \\
\hline Never & 1 & 3 \\
\hline Current/former & 3 & 3 \\
\hline \multicolumn{3}{|l|}{ ECOG PS } \\
\hline $0-1$ & 3 & 4 \\
\hline 2 & 1 & 2 \\
\hline \multicolumn{3}{|l|}{$\begin{array}{l}\text { Types of } E G F R \text { mutation status } \\
\text { prior to start of study }\end{array}$} \\
\hline Exon 19 deletion & 2 & 3 \\
\hline L858R & 2 & 3 \\
\hline \multicolumn{3}{|l|}{ No. of prior regimens } \\
\hline 1 & 0 & 0 \\
\hline 2 & 0 & 0 \\
\hline$\geq 3$ & 4 & 6 \\
\hline \multicolumn{3}{|l|}{ No. of prior EGFR-TKI regimens } \\
\hline \multicolumn{3}{|l|}{1} \\
\hline 0 & 4 & \\
\hline 2 & 1 & 2 \\
\hline 3 & 3 & 0 \\
\hline \multicolumn{3}{|l|}{ Total duration of previous } \\
\hline \multicolumn{3}{|l|}{ EGFR-TKI treatment } \\
\hline$<1$ year & 1 & 0 \\
\hline$\geq 1$ years & 2 & 3 \\
\hline$\geq 2$ years & 1 & 1 \\
\hline$\geq 3$ years & 0 & 2 \\
\hline \multirow{2}{*}{\multicolumn{3}{|c|}{ Last treatment before }} \\
\hline & & \\
\hline EGFR-TKI & 2 & 0 \\
\hline Immune checkpoint inhibitor & 1 & 3 \\
\hline Cytotoxic chemotherapy & 1 & 3 \\
\hline \multicolumn{3}{|l|}{ Stage } \\
\hline M1a & 0 & 1 \\
\hline M1b & 4 & 5 \\
\hline CEA, median (IQR) & $644(58.6-1858.7)$ & $51.5(4.2-66.7)$ \\
\hline
\end{tabular}

ECOG, Eastern Cooperative Oncology Group; PS, performance status; EGFR, epidermal growth factor receptor; TKI, tyrosine kinase inhibitor; ctDNA, circulating tumor DNA; CEA, carcinoembryonic antigen; IQR, interquartile range.

Clinical response to osimertinib. Eleven patients, including one patient who was plasma T790M-positive but tissue T790M status-unknown, were administered osimertinib. Response to osimertinib is shown in Figure 1. Eight patients achieved partial response (PR) and 3 patients had stable disease (SD). No patient achieved complete response (CR) or had progressive disease (PD). The objective response rate (ORR) in T790M-positive patients for all patients, tissue-

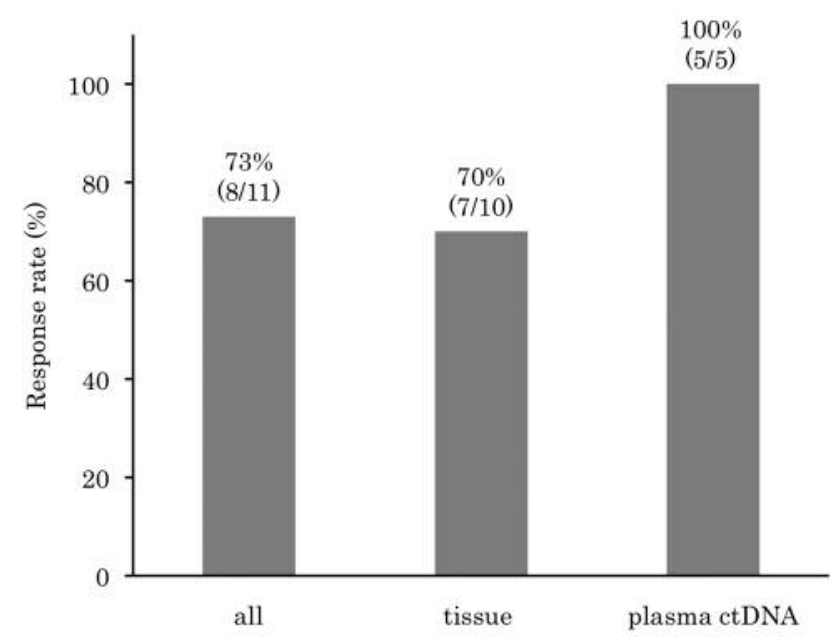

Figure 1. Clinical response to osimertinib according to T790M-positive samples.

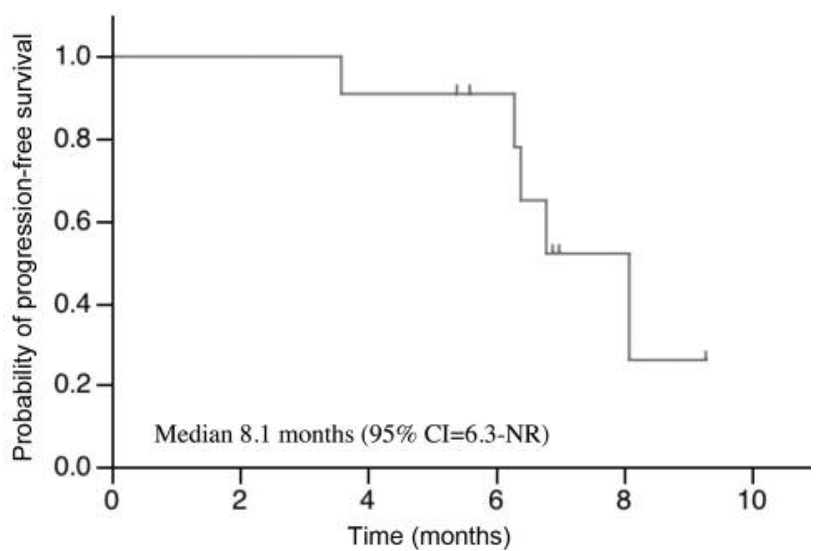

Figure 2. Kaplan-Meier curve for progression-free survival. CI, Confidence interval; NR, not reached.

positive patients, as well as plasma-positive patients, was $73 \%, 70 \%$ and $100 \%$, respectively. Although sensitivity was moderate, the response rate for plasma T790M-positive patients was $100 \%$. The median PFS was 8.1 months $(95 \%$ confidence interval $(\mathrm{CI})=6.3$-not reached $(\mathrm{NR})$ (Figure 2), similar with previous reports.

\section{Discussion}

Although tissue biopsy is a standard procedure to characterize tumor genetics, tissue samples are not always available. Thus, non-invasive plasma ctDNA for EGFR mutation testing has been developing recently as an alternative method to tissuebased testing. To date, several methods of detecting EGFR 
mutations from plasma ctDNA have been reported (15). The PNA-LNA clamp method is a highly sensitive polymerase chain reaction (PCR) method and one of the major methods applied to assess EGFR mutations in tissue or cytology samples in Japan $(12,16)$; however, data for the PNA-LNA clamp method with plasma ctDNA are limited for validating the T790M mutation status in patients who progressed on previous EGFR-TKIs treatment.

In this study, the sensitivity and specificity of the PNA-LNA clamp method for T790M mutation in plasma ctDNA were $40 \%$ and $100 \%$, respectively, and the overall concordance between tissue and plasma samples was $71 \%$. In addition, the response rate to osimertinib in plasma T790M-positive patients was equivalent to that in tissue T790M-positive patients $(100 \%$ vs. $70 \%$ ). Furthermore, one of six patients who were unable to undergo tissue re-biopsy was plasma T790M-positive and responded to osimertinib. Considering these results, plasma-based testing using the PNA-LNA clamp method may be feasible as an initial step to detect T790M in patients who had relapsed after EGFR-TKI treatment and it may be acceptable to use osimertinib in plasma T790M-positive patients detected by the PNA-LNA clamp method without tissue re-biopsy. On the other hand, our study also indicated that tissue biopsy is necessary when plasma T790M is negative because of the high false-negative rate, in line with previous studies using different assays (17-19).

In the current study, all plasma T790M-positive patients had extrathoracic metastases (M1b). In a previous work, plasma T790M positivity was more frequent in M1b disease compared to M0/M1a disease (20). In addition, the serum CEA level was numerically higher for plasma T790Mpositive patients than plasma T790M-negative patients in this study. These results suggest that high tumor burden or diffuse tumor spread may be reflected in the high amount of plasma ctDNA. The possibility of false-negatives should be considered, especially in patients with $\mathrm{M} 0 / \mathrm{M} 1 \mathrm{a}$ disease and normal serum CEA levels.

In conclusion, our study demonstrated the modest sensitivity and high specificity of the PNA-LNA clamp method for detecting plasma T790M in NSCLC patients previously treated with EGFR-TKIs. It also showed that plasma T790M positivity could be a predictive factor for osimertinib. Thus, plasma EGFR T790M testing by the PNA-LNA clamp method may be adequate for the initial step; however, as a result of its high false-negative rate, tissue biopsy is inevitable in plasma T790M-negative patients. As far as understanding these limitations, liquid biopsy using the PNA-LNA clamp method can be routinely used to detect T790M in NSCLC patients treated previously with EGFR-TKIs in clinical practice.

\section{Conflicts of Interest}

The Authors declare no conflicts of interest.

\section{Acknowledgements}

This study was supported, in part, by a Grant-in-Aid for Cancer Research from the Japanese Ministry of Education.

\section{References}

1 Mok TS, Wu YL, Thongprasert S, Yang CH, Chu DT, Saijo N, Sunpaweravong P, Han B, Margono B, Ichinose Y, Nishiwaki Y, Ohe Y, Yang JJ, Chewaskulyong B, Jiang H, Duffield EL, Watkins CL, Armour AA and Fukuoka M: Gefitinib or carboplatin-paclitaxel in pulmonary adenocarcinoma. N Engl J Med 361: 947-957, 2009.

2 Rosell R, Carcereny E, Gervais R, Vergnenegre A, Massuti B, Felip E, Palmero R, Garcia-Gomez R, Pallares C, Sanchez JM, Porta R, Cobo M, Garrido P, Longo F, Moran T, Insa A, De Marinis F, Corre R, Bover I, Illiano A, Dansin E, de Castro J, Milella M, Reguart N, Altavilla G, Jimenez U, Provencio M, Moreno MA, Terrasa J, Muñoz-Langa J, Valdivia J, Isla D, Domine M, Molinier O, Mazieres J, Baize N, Garcia-Campelo R, Robinet G, RodriguezAbreu D, Lopez-Vivanco G, Gebbia V, Ferrera-Delgado L, Bombaron P, Bernabe R, Bearz A, Artal A, Cortesi E, Rolfo C, Sanchez-Ronco M, Drozdowskyj A, Queralt C, de Aguirre I, Ramirez JL, Sanchez JJ, Molina MA, Taron M and Paz-Ares L: Erlotinib versus standard chemotherapy as first-line treatment for European patients with advanced EGFR mutation-positive nonsmall-cell lung cancer (EURTAC): A multicentre, open-label, randomised phase 3 trial. Lancet Oncol 13: 239-246, 2012.

3 Yang JC, Wu YL, Schuler M, Sebastian M, Popat S, Yamamoto N, Zhou C, Hu CP, O'Byrne K, Feng J, Lu S, Huang Y, Geater SL, Lee KY, Tsai CM, Gorbunova V, Hirsh V, Bennouna J, Orlov S, Mok T, Boyer M, Su WC, Lee KH, Kato T, Massey D, Shahidi M, Zazulina V and Sequist LV: Afatinib versus cisplatinbased chemotherapy for EGFR mutation-positive lung adenocarcinoma (LUX-Lung 3 and LUX-Lung 6): Analysis of overall survival data from two randomised, phase 3 trials. Lancet Oncol 16: 141-151, 2015.

4 Yu HA, Arcila ME, Rekhtman N, Sima CS, Zakowski MF, Pao W, Kris MG, Miller VA, Ladanyi M and Riely GJ: Analysis of tumor specimens at the time of acquired resistance to EGFR-TKI therapy in 155 patients with EGFR-mutant lung cancers. Clin Cancer Res 19: 2240-2247, 2013.

5 Goss G, Tsai CM, Shepherd FA, Bazhenova L, Lee JS, Chang GC, Crino L, Satouchi M, Chu Q, Hida T, Han JY, Juan O, Dunphy F, Nishio M, Kang JH, Majem M, Mann H, Cantarini M, Ghiorghiu S and Mitsudomi T: Osimertinib for pretreated EGFR Thr790Met-positive advanced non-small-cell lung cancer (AURA2): A multicentre, open-label, single-arm, phase II study. Lancet Oncol 17: 1643-1652, 2016.

6 Jänne PA, Yang JC, Kim DW, Planchard D, Ohe Y, Ramalingam SS, Ahn MJ, Kim SW, Su WC, Horn L, Haggstrom D, Felip E, Kim JH, Frewer P, Cantarini M, Brown KH, Dickinson PA, Ghiorghiu S and Ranson M: AZD9291 in EGFR inhibitor-resistant non-small-cell lung cancer. N Engl J Med 372: 1689-1699, 2015.

7 Levy B, Hu ZI, Cordova KN, Close S, Lee K and Becker D: Clinical utility of liquid diagnostic platforms in non-small cell lung cancer. Oncologist 21: 1121-1130, 2016.

8 Haber DA and Velculescu VE: Blood-based analyses of cancer: Circulating tumor cells and circulating tumor DNA. Cancer Discov 4: 650-661, 2014. 
9 Snyder MW, Kircher M, Hill AJ, Daza RM and Shendure J: Cell-free DNA comprises an in vivo nucleosome footprint that informs its tissues-of-origin. Cell 164: 57-68, 2016.

10 Douillard JY, Ostoros G, Cobo M, Ciuleanu T, Cole R, McWalter G, Walker J, Dearden S, Webster A, Milenkova T and McCormack R: Gefitinib treatment in EGFR mutated caucasian NSCLC: Circulating-free tumor DNA as a surrogate for determination of EGFR status. J Thorac Oncol 9: 1345-1353, 2014.

11 Mok T, Wu YL, Lee JS, Yu CJ, Sriuranpong V, Sandoval-Tan J, Ladrera G, Thongprasert S, Srimuninnimit V, Liao M, Zhu Y, Zhou C, Fuerte F, Margono B, Wen W, Tsai J, Truman M, Klughammer B, Shames DS and Wu L: Detection and dynamic changes of EGFR mutations from circulating tumor DNA as a predictor of survival outcomes in NSCLC patients treated with first-line intercalated erlotinib and chemotherapy. Clin Cancer Res 21: 3196-3203, 2015.

12 Reck M, Hagiwara K, Han B, Tjulandin S, Grohé C, Yokoi T, Morabito A, Novello S, Arriola E, Molinier O, McCormack R, Ratcliffe $M$ and Normanno N: ctDNA Determination of EGFR mutation status in european and Japanese patients with advanced NSCLC: The ASSESS study. J Thorac Oncol 11: 1682-1689, 2016.

13 Nagai Y, Miyazawa H, Huqun, Tanaka T, Udagawa K, Kato M, Fukuyama S, Yokote A, Kobayashi K, Kanazawa M and Hagiwara $\mathrm{K}$ : Genetic heterogeneity of the epidermal growth factor receptor in non-small cell lung cancer cell lines revealed by a rapid and sensitive detection system, the peptide nucleic acid-locked nucleic acid PCR clamp. Cancer Res 65: 7276-7282, 2005.

14 Watanabe K, Fukuhara T, Tsukita Y, Morita M, Suzuki A, Tanaka $\mathrm{N}$, Terasaki $\mathrm{H}$, Nukiwa $\mathrm{T}$ and Maemondo M: EGFR mutation analysis of circulating tumor DNA using an improved PNALNA PCR clamp method. Can Respir J 2016: 5297329, 2016.

15 Levy B, Hu ZI, Cordova KN, Close S, Lee K and Becker D: Clinical utility of liquid diagnostic platforms in non-small cell lung cancer. Oncologist 21: 1121-1130, 2016.

16 Tanaka T, Nagai Y, Miyazawa H, Koyama N, Matsuoka S, Sutani A, Huqun, Udagawa K, Murayama Y, Nagata M, Shimizu Y, Ikebuchi K, Kanazawa M, Kobayashi $\mathrm{K}$ and Hagiwara $\mathrm{K}$ : Reliability of the peptide nucleic acid-locked nucleic acid polymerase chain reaction clamp-based test for epidermal growth factor receptor mutations integrated into the clinical practice for non-small cell lung cancers. Cancer Sci 98: 246-252, 2007.
17 Thress KS, Brant R, Carr TH, Dearden S, Jenkins S, Brown H, Hammett $T$, Cantarini $M$ and Barrett JC: EGFR mutation detection in ctDNA from NSCLC patient plasma: A crossplatform comparison of leading technologies to support the clinical development of AZD9291. Lung Cancer 90: 509-515, 2015.

18 Sueoka-Aragane N, Katakami N, Satouchi M, Yokota S, Aoe K, Iwanaga $\mathrm{K}$, Otsuka K, Morita S, Kimura $\mathrm{S}$ and Negoro S: Monitoring EGFR T790M with plasma DNA from lung cancer patients in a prospective observational study. Cancer Sci 107: 162-167, 2016.

19 Oxnard GR, Thress KS, Alden RS, Lawrance R, Paweletz CP, Cantarini M, Yang JC, Barrett JC and Jänne PA: Association between plasma genotyping and outcomes of treatment with osimertinib (AZD9291) in advanced non-small-cell lung cancer. J Clin Oncol 34: 3375-3382, 2016.

20 Karlovich C, Goldman JW, Sun JM, Mann E, Sequist LV, Konopa K, Wen W, Angenendt P, Horn L, Spigel D, Soria JC, Solomon B, Camidge DR, Gadgeel S, Paweletz C, Wu L, Chien S, O'Donnell P, Matheny S, Despain D, Rolfe L, Raponi M, Allen AR, Park K and Wakelee H: Assessment of EGFR mutation status in matched plasma and tumor tissue of NSCLC patients from a Phase I study of rociletinib (CO-1686). Clin Cancer Res 22: 2386-2395, 2016.
Received March 15, 2017

Revised March 27, 2017

Accepted March 31, 2017 